\title{
Modeling the Political Economy and Multidimensional Factors of COVID-19 Cases in Nigeria
}

\author{
Kazeem Bello Ajide $^{1}$ [D $\cdot$ Olorunfemi Yasiru Alimi $^{1,2} \cdot$ Ridwan Lanre Ibrahim $^{1} \cdot$ Ifeoma Chinenye Nwokolo $^{1}$
}

Received: 23 June 2020 / Revised: 22 October 2020 / Accepted: 29 October 2020 / Published online: 9 November 2020

(C) Springer Nature Switzerland AG 2020

\begin{abstract}
Both the clinical and epidemiological significance attached to COVID-19 cases by a small, but growing literature on coronavirus are not in any way undermined by the relevance of political economy and multidimensional impacts of other factors on the virus, particularly from country specific stance. In light of the stark reality, this study unravels the political economy and multidimensional factors of COVID-19 cases in Nigeria using the daily data spanning 27th of February through 26th of May, 2020. This paper deploys a variety of count data estimators to estimate the effects of political economy and ethno-religious factors on COVID-19 cases in Nigeria. The parameter estimates reveal that the odds of the Hausa ethnic group in human-to-human transmission of the virus, to be in the "Certain Zero" group is relatively less as compared to other ethnic groups in the country. A plausible reason, particularly for the vulnerable group can be attributed, in part, to their low levels of educational attainment as well as their staunch religious belief with respect to the act of soul taking as being the exclusive property of the creator than the created. Thus, addressing ethno-religious concerns together with socioeconomic factors remain the formidable mitigation policy choices to combating the scourge of the global virus of COVID-19.
\end{abstract}

Keywords Clinical and epidemiology $\cdot$ COVID-19 $\cdot$ Political economy $\cdot$ Count data estimators $\cdot$ Nigeria

\section{Introduction}

The recent scholarship on coronavirus (COVID-19) has been largely devoted to examining clinical and epidemiological features of the infectious disease, thus making little or nothing to be known about the political economy of the pandemic, as well as other multidimensional drivers of the virus,

Kazeem Bello Ajide

kazeemajide@gmail.com

Olorunfemi Yasiru Alimi

alimi.olorunfemi@lcu.edu.ng; haleephemy480@gmail.com

Ridwan Lanre Ibrahim

lanrid23@gmail.com

Ifeoma Chinenye Nwokolo

ifynwokolo76@yahoo.com

1 Department of Economics, Faculty of Social Science, University of Lagos, Akoka, Yaba, Lagos state, Nigeria

2 Department of Economics, Faculty of Environment, Social and Management Sciences, Lead City University, Lagos-Ibadan Express way, Ibadan, Oyo state, Nigeria particularly from country-specific perspective. Two reasons can, at least, be offered as limiting our understanding of the political economy of the novel virus. First, a survey of extant literature reveals that limited studies exist on the virus. Second, in spite of the sparseness in the underlining literature, focuses of the available studies have largely been on the clinical and epidemiological aspect of the virus, thus signifying inadvertent neglect of the impactful role of the political economy dimension. These two reasons motivate the interest of this inquiry.

Indisputably, the world has been ravaged by a variety of coronaviruses in the past, such include the Severe Acute Respiratory Syndrome (SARS) from China (in 2002), the Middle East Respiratory Syndrome (MERS) from Saudi Arabia (in 2012), the Western African Ebola virus from Guinea (between 2013 and 2016), and to the Zika virus from Brazil (in 2015). However, the novel virus-the COVID-19remains the most threatening and fearful owing mainly to the speedy rate of human-to-human transmission across both the time and space. Presently, virtually all countries of the world have had their fair share of the pandemic. As at 20 of October 2020, daily situation reports show that, the novel virus has infected not less than 40,874,256 people from 215 
countries with recorded deaths amounting to $1,126,263$ while $30,481,440$ people have fully recovered from the virus (Worldometer 2020).

Undeniably, the rate at which the virus spreads across the board is astoundingly alarming and unprecedented in human history. With this stark reality, the concern however, lies in unraveling the political economy that has characterized the Nigerian episode. The country provides a natural laboratory for testing the political economy perspective because of the alleged inflated figures of COVID-19 cases among the states of the Nigerian federation coupled with some side commentaries among the political pundits and influential voices. Indeed, this is not unexpected given the structural and political composition of the Nigerian state. Unlike other federalism, the constituent units (the states) of the Nigerian state are unarguably largely dependent on the federal government for socioeconomic and political sustenance. For instance, the current revenue sharing formula ${ }^{1}$ gives the country's Federation Account $52.68 \% ; 26.72 \%$ goes to the states and the remaining $20.60 \%$ is being shared among the 774 local governments across the country (see, Federation Account Committee (FAAC 2020). Thus, the monoculture nature of the economy ${ }^{2}$ further compounds the issue surrounding the political economy of the coronavirus epidemic in the country. This being the case as the crude oil revenues remains the single most important fiscal means of sustenance, which other constituent states depend.

The coronavirus incident was first recorded in Lagos on 27th of February, 2020 after an encounter with an Italian expatriate returning from Milan. Since then, the confirmed cases of the state and that of other states have taken upward trends amounting to 61,307 with recovered and death records standing at 56,557 and 1123 as at 17th October, 2020 (NCDC 2020). Lagos state seems to be topping the chart with respect to the number of confirmed cases, recovered and deaths (see Fig. 3 below for visual confirmation). Consequently, the cases of other states suddenly leapfrogged to an unimaginable level. What actually explains the sudden change in reported cases, among other states of the federation? This remains an empirical issue.

The core of most side comments relates directly to the issue surrounding the political economy of the intervention fund of A10 billion that was given to Lagos on 27th of March 2020 . The state equally received supports both financial and in kinds, from well over two hundred private organizations and Non-Governmental Organizations $(\mathrm{NGOs})^{3}$ alike. For

\footnotetext{
$\overline{1}$ The sharing formula has continued to be a source of constant controversies and agitations among the constituent units to date. However, this is not the focus of our study.

${ }^{2}$ According to International Monetary Fund (IMF), the Nigerian economy is heavily dependent on the oil sector, which, accounts for over $95 \%$ of export earnings and about $40 \%$ revenues.

${ }^{3}$ For full details, visit: https://civichive.org/covidtracka/covid-donations/
}

instance, the United Bank for Africa (UBA) gave out the sum of 1 billion Naira; the Guaranty Trust Bank (GTB) handed out 110 fully furnished isolation centers; and other donations received include: 50 million Naira from the Multi-choice Nigeria; 200 million Naira from the Famfa Oil Limited; 100 million Naira from the Nigerian Breweries; 500 million Naira from the Ronald Chagoury; 500 million Naira from the Gilbert Chagoury; and 500 million Naira from the Mike Adenuga Jnr. Upon the disbursements, the reported COVID19 cases soon spread across other states of the federation.

More worrisome are the anecdotal evidences pointing to politicization of the cases being reported by Nigeria Centre for Disease Control (NCDC) ${ }^{4}$ as fictitious and being largely falsified. This with the intent of allowing other states in the federation, partaking in what seems to be regarded as "Federal Government largesse" purported to have been curved out from the Federation Pool Account (FPA). Instances abound on the influential voices on the politicization of the spread of COVID-19 pandemic for the country. For instance, echoing the excerpt of the comments of the Governor of River State (Ezenwo Nyesom Wike) “.....it is unfortunate that the containment of coronavirus has been politicized by the Federal Government. While Lagos State received a grant of $\mathrm{N} 10$ billion as a commercial hub, River State, as the nation's oil and gas hub that produces a greater percentage of the nations' wealth, has not received any support from the Federal government" (Daily Post April 6, 2020). Similarly, the former Minster of Transportation for Nigeria (Ebenezer Babatope) has this to say "....it is wrong to play politics with the disease... This is not the time to play PDP, APC or APGA. This is an emergency situation because people are dying. We must not play silly and irresponsible politics with the pandemic" (Todayng, May 6, 2020). The former President of Nigeria (General Ibrahim Badamasi Babangida) remarked: "Don't politicize efforts to tackle COVID 19...this is not the time to 'play game' but a concerted effort by all to wage a total war against the killer disease" (Vanguard Newspaper, April 12, 2020). In light of these seemingly unverified claims, our study hopes to add to the literature on coronavirus in three areas: First, to model the political economy surrounding statesfederal government interaction on the incidence of Covid19; Second, to estimate the multidimensional factors driving the COVID-19 cases in Nigeria. Finally, to add to the scanty literature from the country-specific orientation.

To preview our findings, the parameter estimates of the models reveal that the odds of the Hausa ethnic group in human-to-human transmission of the virus to be in the "Certain Zero" group is relatively less than other ethnic groups in Nigeria. The reasons for this outcome particularly for the vulnerable group can be attributed, in part, to their low levels

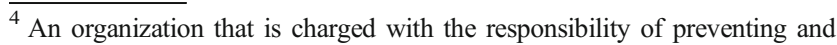
controlling the spread of diseases in Nigeria
} 
of educational attainment as well as their staunch religious belief with respect to the act of soul taking as being the exclusive property of the creator than the created.

Following the introductory section, "Stylized Facts" section presents an apt literature review of the previous empirics, with "Stylized Facts" section discussing the stylized facts about the spatial dimension of the virus. "Model Building" section builds the theoretical model of the political economy underlying the COVID-19 spread in Nigeria, while "Data and Methodology" section presents the data and methodological issue adopted. "Analysis of Empirical Results" section analyzes the empirical findings, while "Discussion of Results" section concludes with policy implications.

\section{Literature Review}

\section{A Brief Review of Extant Literature}

The recent challenges posed by the emergence of COVID-19 on the global economy have received widespread attention from international community, health policy pundits, and academic researchers, directing efforts at understanding the features, causes, and impacts of the novel virus. The preponderance of these studies had identified a number of factors as possible driving forces behind the deadly virus. These include but not limited to: respiratory syndrome (Al-Raddadi et al. 2020); governance, technology, and citizen behavior (Shaw et al. 2020); socio-economic impacts (Nicola et al. 2020); temperature (Briz-Redón and Serrano-Aroca 2020); spatial variation (Guliyev 2020); climatic factors (Altamimi and Ahmed 2020; Tosepu et al. 2020); prevalence and control measures (Ceylan 2020; Zhao et al. 2020) and mortality rates (Ferdinand and Nasser 2020; Wang et al. 2020); social and political economy (Daniel 2020; Greer et al. 2020; Saleh 2020); and lockdown impacts (Ajide et al. 2020; Ibrahim et al. 2020).

Notwithstanding the foregoing, a painstaking assessment of the extant literature brings to the open at least certain limitations of which three are prominent. First, the available studies are more disposed towards unraveling the epidemiological and clinical features of the novel virus with little or nothing known about the political e, e.g., like Nigeria, more often than not, affects the integrity of report on COVID-19 infection on the one hand, that the intervention resources or funds come from the central government to the affected states on the other hand, makes the political economy dimension imperative. Second, examining other multi-dimensional factors such as surface area, ethnical variation, religious diversity, natural resources, and mobility, makes this idea novel. Lastly, most of the available literature largely employs descriptive approach and simple ordinary least squares (OLS) method of analysis; this study moves a step further to deploy a variety of estimators of count data to achieve the stated objectives.

\section{Stylized Facts}

This section presents the stylized facts on the spatial dimension of COVID-19, extending the argument towards other continents other than Nigeria as well.

Irrefutably, the COVID-19 started in China, precisely Wuhan province, and spread from there to other continents, regions, countries, and cities. At present, of the continents in the world, the confirmed and active cases of North America seem to be topping the virus scorecard. This is directly followed by the Europe who surpasses the North America in recovery cases. The least of the cases is credited to the Oceania as can be observed from Fig. 1. In Africa, South Africa appears to be leading in confirmed cases of COVID-19 while Egypt takes the second position. However, the latter country edges out the former in regard to active cases as depicted in Fig. 2. A third-place position is assumed by Nigeria, with Guinea being the least. In Nigeria, specifically, Lagos state appears to be leading on all counts-confirmed, active and recovered, respectively (see Fig. 3).

\section{The Context ${ }^{5}$}

Nigeria is a country on the coast of West Africa, bordered in south by the Bight of Benin and the Bight of Biafra (Bight of Bonny), both part of the Gulf of Guinea, by Niger in north, Benin in west, Cameroon in south east, and by Chad in north east by a boundary across Lake Chad. The nation shares maritime borders with Equatorial Guinea, Ghana, and São Tomé and Príncipe. With an area of $923,768 \mathrm{~km}^{2}$, the country is more than three times the size of Italy or slightly more than twice the size of the US state California. Nigeria's main rivers are the Niger and the Benue River; its highest point is Chappal Waddi with $2419 \mathrm{~m}$ (7936 ft), located in Taraba State, near the border with Cameroon. The Federal Republic of Nigeria (its official name) has a population of 200 million people (National Bureau of Statistics 2019) making it Africa's most populous country. Capital city is Abuja located in the center of the nation, while Lagos is the primary port and largest city. Spoken languages are English (official), Hausa, Ibo, Yoruba, and others. The detailed map (see Fig. 4) below is showing Nigeria and surrounding countries with international borders, Nigeria's administrative divisions (states), state boundaries, the national capital Abuja, and state capitals.

\footnotetext{
${ }^{5}$ Excerpts from Wikipaedia.
} 
Fig. 1 Global trend in COVID-19

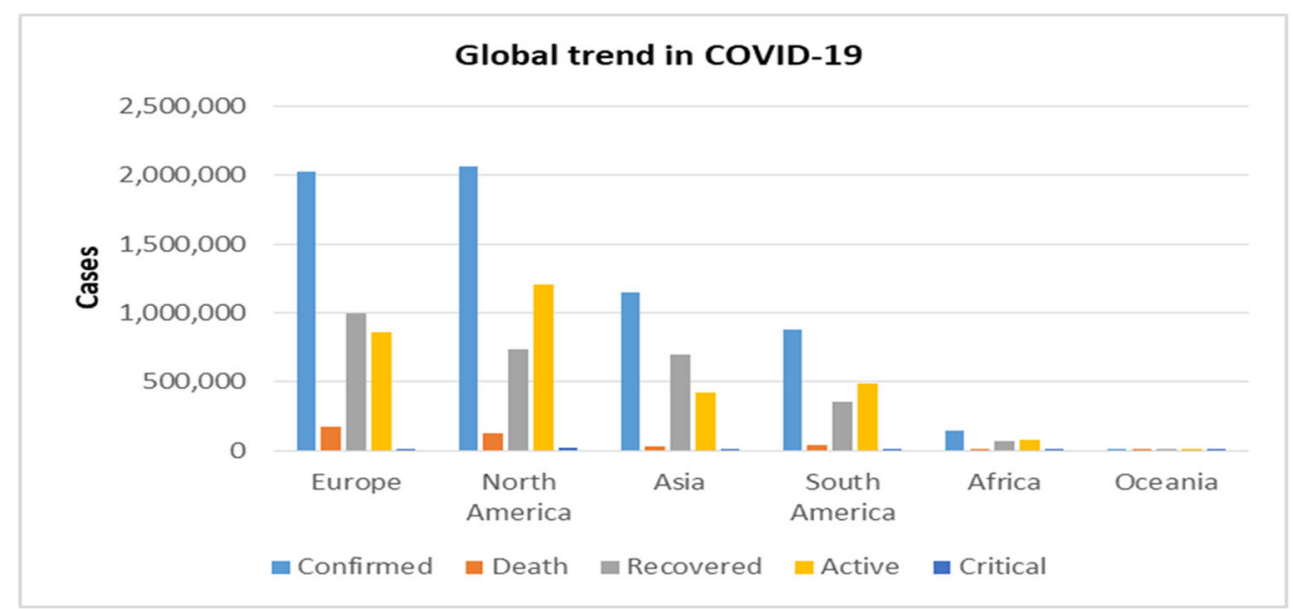

\section{Model Building}

We try to model the possible interactions between the states and Federal government in the allocation and disbursement of resources with respect specifically to COVID-19 goods and consumption of other private goods. To put the strategic relationship in perspective, we commence by developing a simple model of political economy underlying the relationship between the state governments (consisting of both government party and non-governmental party) and federal government on the administration and treatment of COVID-19 cases in Nigeria. These two categories of governments constitute the main actors in this model. For simplicity, we equally assume two commodities in the model. The first commodity represents the representative state's consumption of private goods, and the other commodity is state's consumption of the welfare-enhancing good (COVID-19 good) which can either be purchased by the state or the federal government (e.g., ventilator, hand-sanitizer machines, other COVID-19 drugs). The funding of the latter goods does not affect the commodity's marginal utility. This implies that the quality of the welfare-improving commodity is the same regardless of who supplies it, although state government would prefer the federal government to supply these commodities. These types of products, for instance, include basic COVID-19 goods such as those earlier mentioned. These do not include welfareimproving products that require substantial fixed costs, such as the construction of COVID-19 hospitals or other capitalintensive COVID-19 items that can be funded only by the federal government because it may be prohibitively expensive for a state government to shoulder.

\section{The Representative State's Problem}

State governments have the following Cobb-Douglass utility function over these two types of commodities.

$U(c, s, f)=\varphi \log (c)+(1-\varphi) \log (s+f)$

where $c$ is the representative state's consumption of private goods, $s$ is the state's consumption of the welfare-improving good (COVID-19 goods), and fis the federal government's provision of COVID-19 goods. The parameter $\varphi$ is the weight that the state governments place on the private consumption

Fig. 2 African trend in COVID-

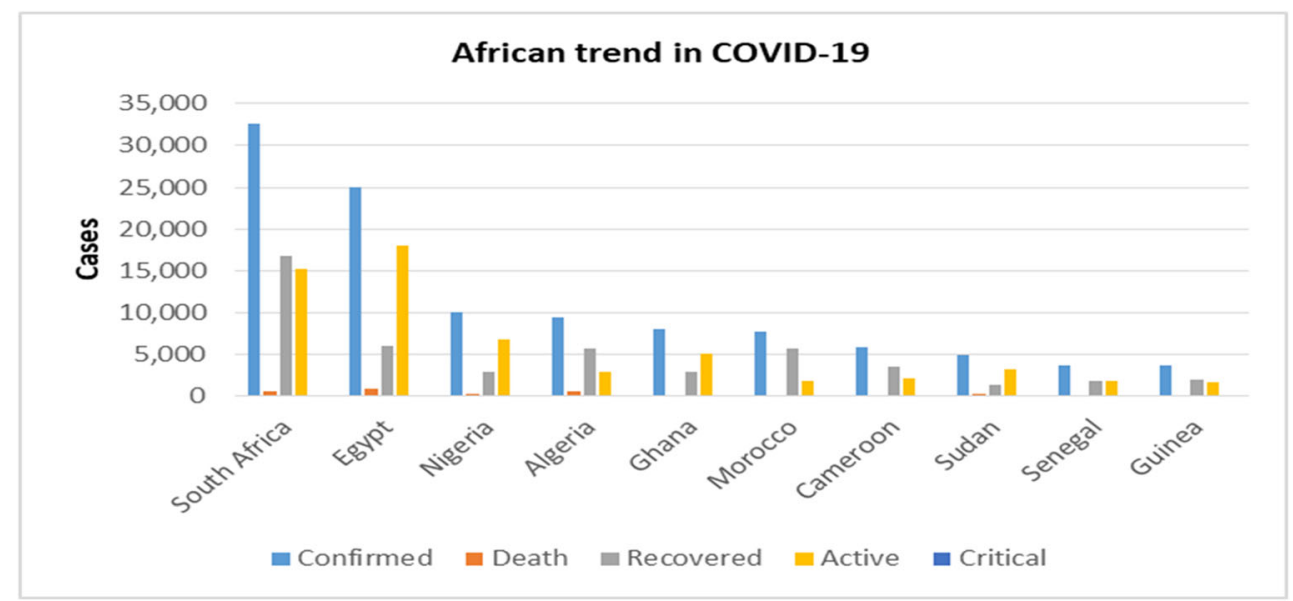


Fig. 3 Nigerian trend in COVID19
Nigerian trend in COVID-19

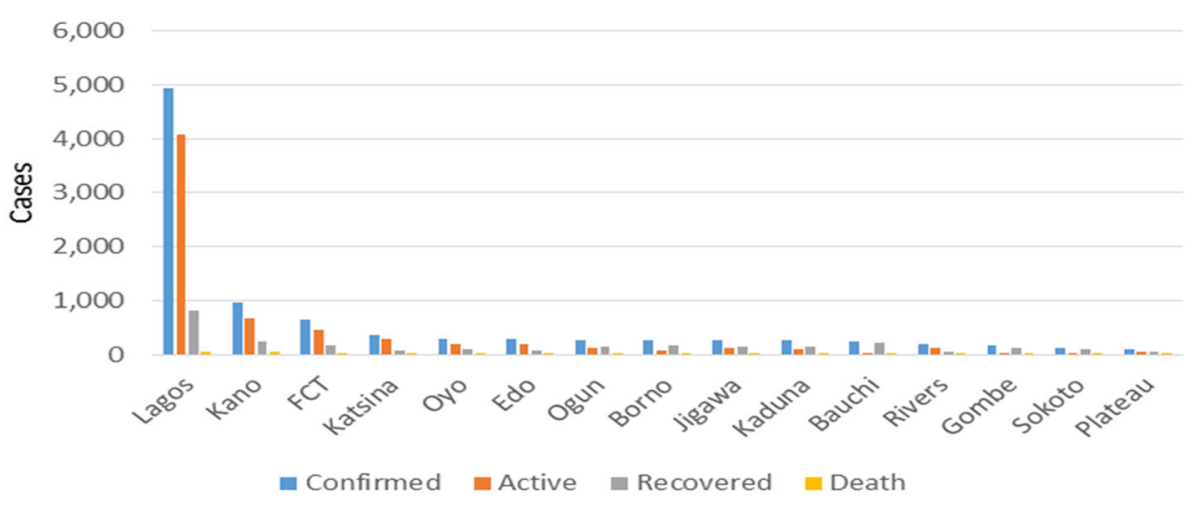

goods relative to welfare-improving goods. The parameter lies within the bound of 0 and 1 . State governments finance their expenditures subject to their budget constraint of the form:

$$
T+\mathrm{OR}+F_{\text {Allocation }}=s+f
$$

where $T$ is the tax income, ORstands for other state's revenue generated and $F_{\text {Allocation }}$ represents the allocation received by the state governments from the federal government. Maximizing Eq. (1) subject to Eq. (2) yields:

$s^{*}=(1-\varphi)\left[\left(T+\mathrm{OR}+F_{\text {Allocation }}\right)\right]-\varphi f$
Interpreting the first-order condition given in Eq. (3) depicts that the states government optimal expenditure on welfare-improving goods are increasing in taxes collected, other revenue generated as well as allocation from the federal government but decreasing in the provision of COVID-19 goods. This means that if the federal government increases its provision of the welfare goods, which in this case are COVID-19 goods, the state governments will cut down her expenditure on those goods. This is because state governments allocate their budgets between $c$ and $s$, if state expenditures on the welfare good rise, then expenditure on private goods must decline and vice versa.

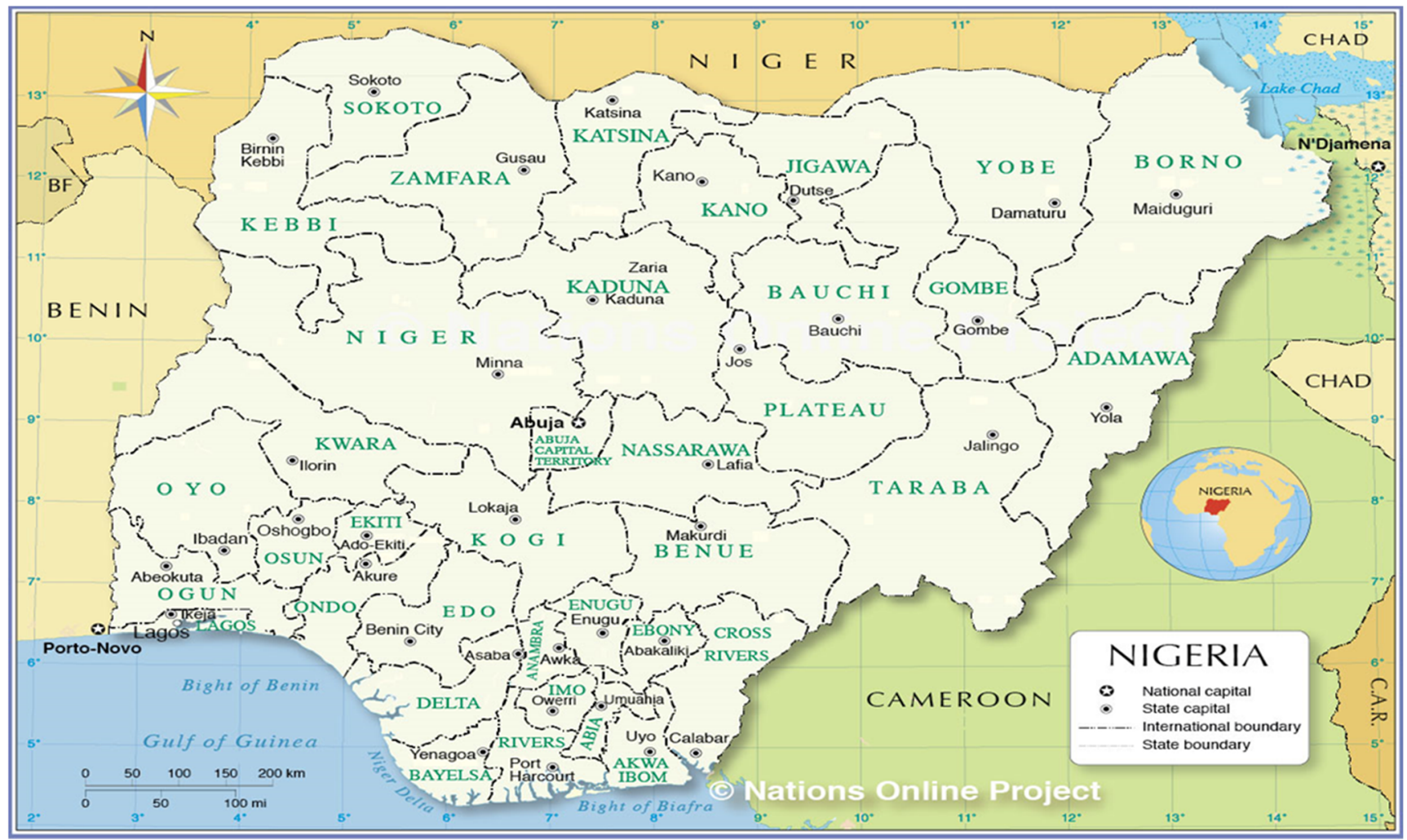

Fig. 4 Map of Nigeria 


\section{The Federal Government's Problem}

Assuming the federal government does not behave like a central planner. It then means in effect, that federal government cares about maximizing a combination of the representative state government's utility (particularly for states in the same party with the federal government $)^{6}$ and its own utility derived from the resources that the federal government reserves for itself. In this case, the federal government's problem consists of maximizing the following objective function stated as:

$\psi(v, U)=\pi \log (f)+(1-\pi) U(v, s, f)$

where $v$ stands for whatever federal government keeps for own consumption. Given these parameters, the federal government chooses $v$ to maximize its survivor function subject to her budget constraint:

$\operatorname{Re}_{\mathrm{rv}}+N \operatorname{Res}_{\mathrm{rv}}=f+v$

where $\operatorname{Re} s_{\mathrm{rv}}$ and $N \operatorname{Re} s_{\mathrm{rv}}$ are the rents from natural resource endowment of the country, and revenue generated from nonresource goods, while other denotations are as previously defined. The interaction between the state governments and federal government is modeled as a one-shot Stackelberg game where the federal government makes the first move. This is so because we assume that since federal government has a full knowledge about the representative states and, the emanating reactions of these state agents to its spending will be factored into its optimization problem. Solving for the equilibrium requires backward induction. Thus, substituting Eq. (5) into (4) gives:

$f^{*}=(1-\pi) \operatorname{Res}_{r v}-\pi N \operatorname{Re}_{r v} \pi$

This Eq. (6) demonstrates that the federal government's optimal provision of COVID-19 goods is increasing in rents from natural resource endowment and decreasing in nonresource revenue. The logic is that federal government would prefer to meet COVID-19 exigencies from the common pool resource (oil rents in this case) than from independent revenue generated. Whatever the federal government does not spend on COVID-19 can be used in the provision of other goods. Dividing through by rents from natural resource endowment, in equilibrium, the government allocates to itself

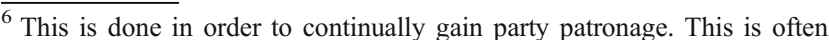
displayed by giving preferences to party from the ruling government in the distribution of rents as well as other concerns bordering on COVID-19 infection. This is similar to the commentaries leveled against the present administration in Nigeria by the opposition party when the Federal government disbursed 10 billion Naira to the Lagos State government (being in the same party with the ruling government) in the fight against COVID-19 pandemic, while other states (e.g., Ibadan) from non-governmental party states was ignored.
}

$\frac{f^{*}}{\operatorname{Res}_{\mathrm{rv}}}=\pi\left(1+\frac{N \operatorname{Res}_{\mathrm{rv}}}{\operatorname{Re} s_{\mathrm{rv}}}\right)$

Equation (7) clearly shows that the federal government's optimal expenditure on other goods is increasing in the revenue generated from non-resource goods as a share of rents from natural resource endowment.

\section{Data and Methodology}

Aside being the most populous country in Africa, Nigeria is the most densely populated Black nation in the world with over 200 million people (National Bureau of Statistics 2019). The country is a territory, housing over 250 ethnic groups with more than 500 languages. The three main ethnic groups are Igbo, Yoruba, and Hausa with approximately $18 \%$, $21 \%$, and $27.4 \%$ of the whole population (The World Fact 2018). The tribes that constituted the other Southeastern populace are Ibibio, Efik, Ijaw, and Annang while those in the Midwest are Edo, Itsekiri, and Urhobo-Isoko (LeVan and Ukata 2018). The three major religions are the Muslims (53.5\%), Christians (45.9\%) (consisting of Roman Catholic $(10.6 \%)$ and other Christians (35.3\%)), and other traditional beliefs are $0.6 \%$ (The World Fact 2019). As for education, states are categorized into two, namely educationally advantaged and educationally disadvantaged states. The categorization was based on the literacy level of states published by the National Bureau of Statistics (2018). States ranked above $50 \%$ are classified as educationally advantaged states while those below $50 \%$ are classified as the educationally disadvantaged states. The twelve states that fall under the educationally disadvantaged states are Kaduna (47\%), Kano (38\%), Gombe (29\%), Jigawa (25\%), Borno (23\%), Niger (23\%), Kebbi (21\%), Bauchi (19\%), Zamfara (19\%), Sokoto (15\%), Katsina (10\%), and Yobe (7\%) respectively. Thus, one is assigned to educationally advantaged states whereas zero if otherwise.

Data on COVID-19-the main dependent variable are sourced from several sources including WHO website, Worldometer, (https://www.worldometers.info/coronavirus/), Google mobility data (https://www.google.com/covid19/ mobility/), Nigeria Centre for Disease Control (NCDC) Situation report (https://covid19.ncdc.gov.ng/), and other sources such as the National Bureau of Statistics 2019) and the World Fact (2018). Our data for the $34^{7}$ states $^{8}$ reveal that for the sample of Nigerian state-level observations, appropriately $75 \%$ had no COVID-19 cases as at the time of writing

\footnotetext{
${ }^{7}$ The states are 36 altogether but two states such as Kogi and Rivers are excluded from our analysis because as at the time of this study, no recorded cases of Covid-19 infection were declared.

${ }^{8}$ See Appendix A for the list of states in Nigeria.
} 
Table 1 Summary statistics

\begin{tabular}{|c|c|c|c|c|c|c|c|c|}
\hline Variables & Measurement & Mean & Std dev. & Kurtosis & Skewness & Max. & Min. & Obs. \\
\hline Cases & Number of reported COVID-19 cases & 3.2154 & 14.022 & 85.910 & 8.4048 & 199 & 0 & 2414 \\
\hline Yoruba & States dominated by Yoruba tribe & 0.2059 & 0.4044 & 0.1191 & 1.4557 & 1 & 0 & 2414 \\
\hline Igbo & States dominated by Igbo tribe & 0.3235 & 0.4679 & -1.4313 & 0.7549 & 1 & 0 & 2414 \\
\hline Hausa & States dominated by Hausa tribe & 0.4706 & 0.4992 & -1.9877 & 0.1179 & 1 & 0 & 2414 \\
\hline Muslim & Muslim dominated states & 0.6765 & 0.4679 & -1.4313 & -0.7549 & 1 & 0 & 2414 \\
\hline Christian & Christian dominated states & 0.3235 & 0.4679 & -1.4313 & 0.7549 & 1 & 0 & 2414 \\
\hline res & States with natural resources abundance & 0.2059 & 0.4044 & 0.1191 & 1.4557 & 1 & 0 & 2414 \\
\hline \multirow[t]{2}{*}{ surface } & Surface area & 9.8450 & 0.8303 & -0.9579 & -0.3220 & 11.243 & 8.115 & 2414 \\
\hline & Surface area $(\log )$ & $25,510.5$ & $18,485.7$ & 0.4478 & 0.9641 & 76,363 & 3345 & 2414 \\
\hline intspt & International airports & 0.2059 & 0.4044 & 0.1191 & 1.4557 & 1 & 0 & 2414 \\
\hline seapt & Seaports & 0.1176 & 0.3223 & 3.6434 & 2.3749 & 1 & 0 & 2414 \\
\hline edu & Education & 0.6471 & 0.4780 & -1.6221 & -0.6158 & 1 & 0 & 2414 \\
\hline apc & States controlled by APC governors & 0.5588 & 0.4966 & -1.9454 & -0.2371 & 1 & 0 & 2414 \\
\hline napc & States controlled by non-APC governors & 0.4412 & 0.4966 & -1.9454 & 0.2371 & 1 & 0 & 2414 \\
\hline
\end{tabular}

COVID, corona virus; Max., maximum; Min., minimum; Std dev., standard deviation; Obs., observation

this study. Given that our main dependent variable is integervalued with a preponderance of zeros, as in Zorn (1998), informing our parameter estimates to be based on count data estimator specifications that take account of the "dual regime" nature of the process of generating COVID-19 infections within the states of the federation. The paucity of COVID19 cases across the states, implying a no infection state regime with some probability of transitioning to a regime where human infection of COVID-19 exists. Thus, this study relies on count data estimators that explicitly take account of a zero regime such as zero-inflation Poisson (Lambert 1992), and zero-inflated negative binomial (Greene 1994), reduce or remove the bias in parameter estimates or specification bias, resulting from over dispersion caused by a preponderance of zeros. These estimators have been widely used in most empirical studies such as Price (2019) and Price and Elu (2017).

Suppose $C_{\mathrm{i}}$, the number of people infected with COVID19 in states $i$ and time $t$, is distributed as a Poisson or negative binomial random variable with mean $\eta_{i}$, let $\varpi_{i}$ be the probability of a state making a transition to the non-zero state of human infections, and $1-\varpi_{i}$, the probability that the state will not make the transition, a dual-regime or zero-inflated count data estimator (Zorn 1998) is based on':

$E\left(C_{\mathrm{it}} / X_{\mathrm{ii}}, Z_{\mathrm{it}}\right)=\varpi_{i} \exp \left(\sum \alpha_{i} X_{\mathrm{it}}\right)$

\footnotetext{
${ }^{9}$ Our specification of a dual-regime zero-inflated count data follows that Long and Freese (2001). For $C_{\mathrm{it}}=c=0,1, \ldots \ldots . N$ and

$\operatorname{Prob}\left(C_{\mathrm{it}}=r\right)=e^{-\eta_{i}} \eta_{i}^{c} / c !$

$\operatorname{Prob}\left(C_{\mathrm{it}}=r\right)=[\Gamma(c+1 / \beta) / \Gamma(1 / \beta) c !] \times\left[(1 / \beta) / 1 / \beta+\eta_{i}\right]^{1 / \beta} \times\left[\eta_{i} / 1 / \beta+\eta_{i}\right]^{c}$

where $\Gamma$ is the Gamma distribution, and $\beta$ is a dispersion parameter.
}

$\varpi_{i}=\exp \left(\sum^{k} \alpha_{i} Z_{\mathrm{it}}\right) / 1+\exp \left(\sum \alpha_{i} Z_{\mathrm{it}}\right)$

Where: $X_{\mathrm{it}}$ and $Z_{\mathrm{it}}$ are exogenous variables, and $\exp \left(\sum^{K} \alpha_{i}\right.$ $\left.X_{\text {it }}\right)=\eta_{i}$ which is the expected value of the number of infected COVID-19 patients.

Estimating the parameters from (8) and (9) constitute a zero-inflated count data regression model, as estimating the Logit specification in (9) provides estimates of the effects of the $X_{\mathrm{it}}$ on remaining in the zero human infection of COVID-19 regime. A total of $K+L$ parameters are estimated, where $K$ is the number of coefficient estimates for the $X_{t}$ that determine $\eta_{i}$, and $L$ is the number of coefficient estimates for the $Z_{i t}$ or "inflators" that determine the always zero terrorism events regime.

Apart from the clinical and epidemiological reasons that have been cited as precipitating the incidence of COVID-19 cases in the medical and clinical literature, there are some other socio-cultural and political factors that could equally make COVID-19 more likely, particularly from countryspecific stance. In our case, we consider the following factors as capable of contributing to COVID-19 cases in Nigeria. Tribe plays a critical role capable of instigating COVID-19 in Nigeria. This can be explained by relating each tribal attitude towards the emergence of COVID-19. Unlike the Yorubas and Igbos, the majority of Hausas do not belief in the existence of COVID-19. This is vividly reflected in the viral video where some pockets of Hausas in Kano were chanting "Babu Corona (meaning, there is no coronavirus)". ${ }^{10}$ Thus, attitudes affect the preventive measures that are likely to

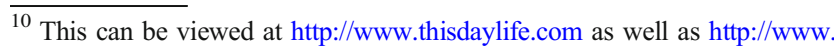
saharareporters.com
} 
Table 2 Correlation matrix

\begin{tabular}{|c|c|c|c|c|c|c|c|c|c|c|c|c|}
\hline & Yoruba & Igbo & Hausa & Muslim & Christian & res & surface & intspt & seapt & edu & apc & napc \\
\hline Cases & 0.206 & -0.123 & -0.052 & 0.135 & -0.135 & -0.079 & -0.195 & 0.263 & 0.284 & 0.010 & 0.142 & -0.142 \\
\hline Yoruba & 1 & -0.352 & -0.480 & 0.197 & -0.197 & -0.079 & -0.242 & 0.101 & 0.040 & 0.376 & 0.306 & -0.306 \\
\hline Igbo & & 1 & -0.652 & -0.866 & 0.866 & 0.581 & -0.565 & -0.041 & 0.333 & 0.511 & -0.525 & 0.525 \\
\hline Hausa & & & 1 & 0.652 & -0.652 & -0.480 & 0.725 & -0.043 & -0.344 & -0.783 & 0.244 & -0.244 \\
\hline Muslim & & & & 1 & -1.000 & -0.581 & 0.575 & 0.041 & -0.333 & -0.511 & 0.525 & -0.525 \\
\hline Christian & & & & & 1 & 0.581 & -0.575 & -0.041 & 0.333 & 0.511 & -0.525 & 0.525 \\
\hline res & & & & & & 1 & -0.317 & -0.079 & 0.491 & 0.376 & -0.134 & 0.134 \\
\hline surface & & & & & & & 1 & -0.113 & -0.364 & -0.566 & 0.148 & -0.148 \\
\hline intspt & & & & & & & & 1 & 0.266 & -0.364 & 0.013 & -0.013 \\
\hline seapt & & & & & & & & & 1 & 0.266 & -0.227 & 0.227 \\
\hline edu & & & & & & & & & & 1 & -0.284 & 0.284 \\
\hline apc & & & & & & & & & & & 1 & -1.000 \\
\hline
\end{tabular}

Cases, number of reported COVID-19 cases; Yoruba, states dominated by Yoruba tribe; Igbo, states dominated by Yoruba tribe; Hausa, states dominated by Hausa tribe; Muslim, Muslim-dominated states; Christian, Christian-dominated states; Res, states with natural resources abundance; surface, surface area; intspt, international airports; seapt, seaports; edu, education; apc, states controlled by APC governors; napc, states controlled by non-APC governors

be taken towards the virus. Religion also influences the spatial and temporal dimensions of COVID-19. If religion supports the existence of COVID-19, the lesser would be the spread, but if religion sees it as a purely divine wrath, which only prayers can resolve without taking proper preventive measures, the more likely the spread of the virus. The resource endowment can also affect the political dimension of COVID19 reported cases. In a situation where each state sees it as a political tactic of obtaining from the Federal government more financial resources, in no distant time, each state would start ascribing more COVID-19 cases to themselves. This scenario is similar to what is happening in the Nigerian case as qualitative evidences have revealed. Surface area is another important predictor candidate of COVID-19. A state with more large surface area, COVID-19 infection will be less likely in such an environment as compared to when a state has a small land surface area, such as Lagos state. Little wonder, the state presently has the highest number of reported cases of COVID-19 (see, Fig. 3). International airports and seaports also constitute the easiest routes through which COVID-19 cases can spread. This is the main route through which countries in the world has contacted the disease, and hence the spread. This typifies the situation in the Nigerian case. The Italian man that came to the country in March through the international airport actually spread the virus. The level of education also greatly determines the level of spread of the virus. Thus, the higher the level of education, the less likely the COVID-19 infection vice versa. The party affiliation equally plays a critical role in the claim of COVID-19 infection. Once a political economy argument is factored into the virus episode, it becomes an issue. This is similar to what has happened in Nigerian case. This is because as soon as 10 billion Naira was allocated to Lagos as palliatives for the people infected with the virus, all other states (non-governmental party) started ascribing more cases of COVID-19 infection.

\section{Preliminary Results}

Table 1 presents summary statistics of the multidimensional variables used in the study. From the Table, it is apparent that the number of reported cases of COVID-19 averaged 3.2 with the maximum being 199. In terms of the major tribes in Nigeria, the Hausa has the highest mean of 0.47 , directly followed by Igbo with 0.32 . This is not surprising given the number of states claimed by the Hausas in the federation. This is even more apparent looking at the Nigerian map above. Undoubtedly, the most practiced religion in Nigeria is Muslim; this is because the Hausas who are mainly Muslims have the highest number of states as earlier alluded. In addition, the states that are well endowed with abundant natural resources averaged 0.2050. By implication, one-fifth of the states in the country are endowed with abundant natural resources. Similarly, the number of international airports and seaports across the country averaged 0.2059 and 0.1176 . The level of education has a mean value of 0.3529 , which is not unexpected as the majority of Hausas who has the highest number of states within the federation are illiterates. On the political arena, the ruling party - the All Progressive Congress (APC) - seems to dominate with an average value of 0.5588 while the non-APC parties averaged 0.4412 . Table 2 presents the correlation matrix, depicting the level of association between and/or among the variables of interest. 


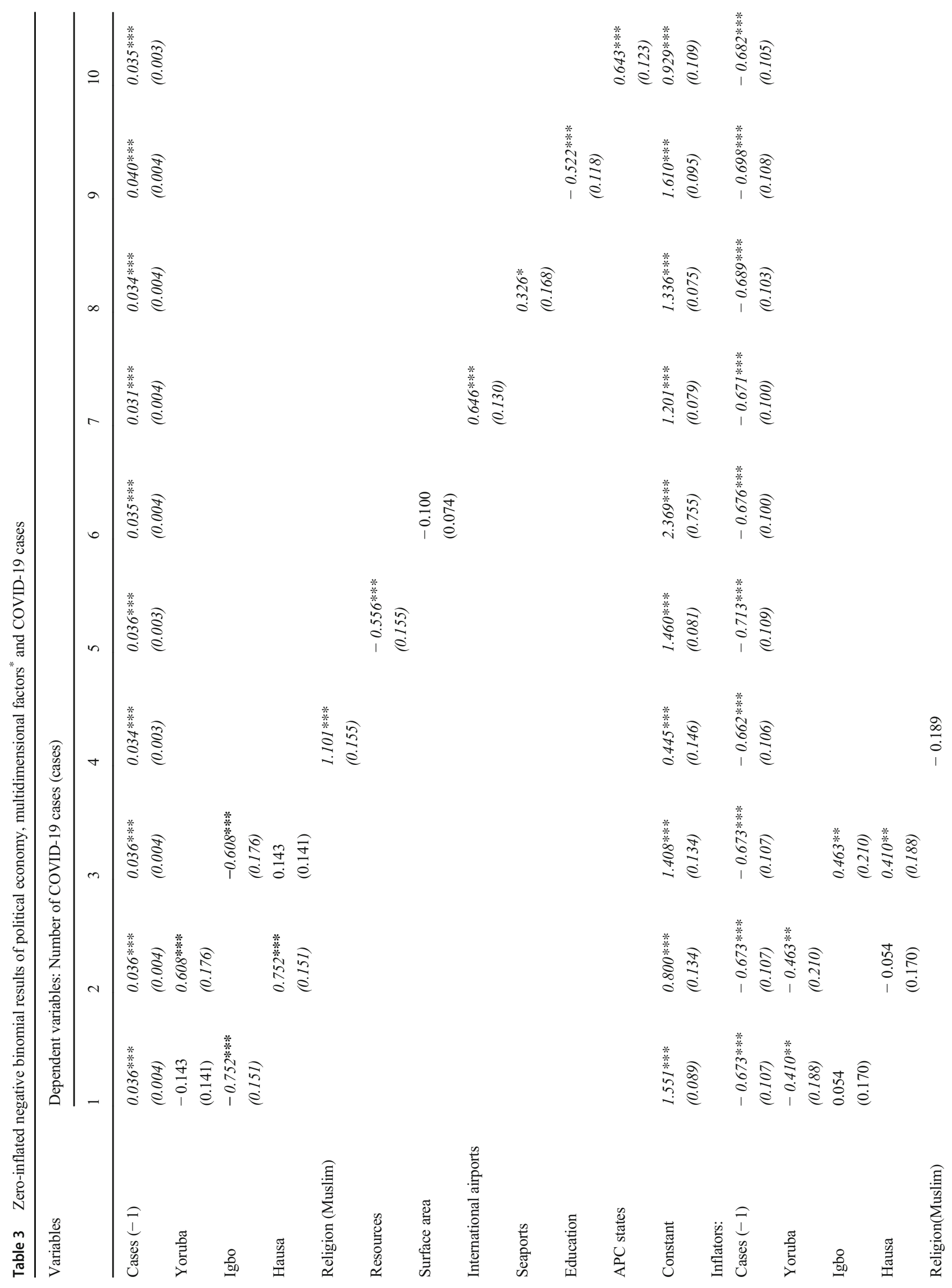




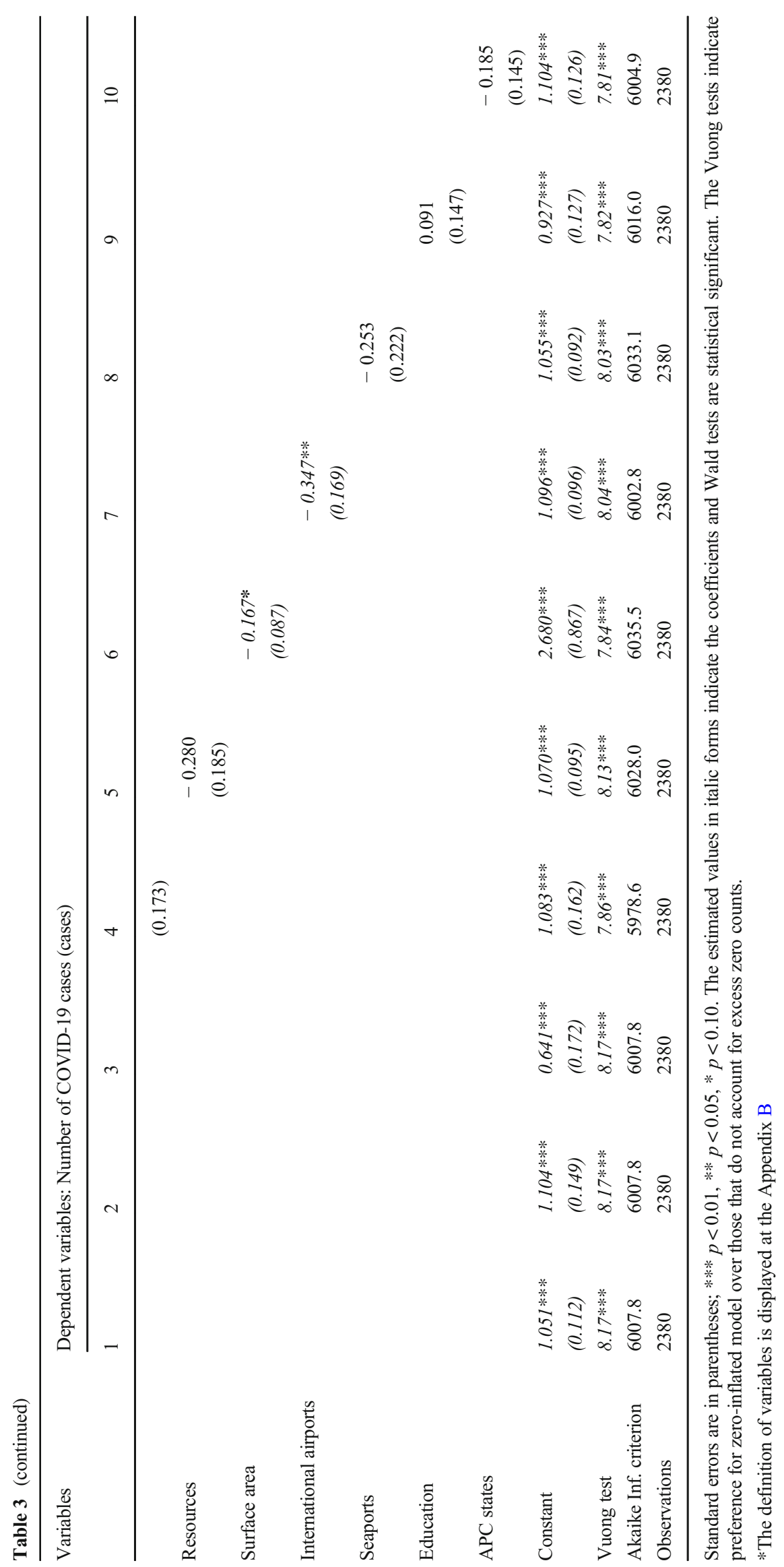


Table 4 Count data estimates of political economy, multidimensional factors, and COVID-19 cases

\begin{tabular}{|c|c|c|c|}
\hline \multirow[t]{2}{*}{ Variables } & \multicolumn{3}{|c|}{ Dependent variables: number of COVID-19 cases (cases) } \\
\hline & $\begin{array}{l}\text { Generalized negative binomial(GNB) } \\
1\end{array}$ & $\begin{array}{l}\text { Zero-inflated negative binomial } \\
2\end{array}$ & $\begin{array}{l}\text { Zero-inflated Poisson } \\
3\end{array}$ \\
\hline \multirow[t]{2}{*}{ Cases $(-1)$} & $0.009 * * *$ & $0.020 * * *$ & $0.011 * * *$ \\
\hline & $(0.002)$ & $(0.004)$ & $(0.000)$ \\
\hline \multirow[t]{2}{*}{ Yoruba } & $0.774 * * *$ & 0.113 & -0.045 \\
\hline & $(0.260)$ & $(0.247)$ & $(0.087)$ \\
\hline \multirow[t]{2}{*}{ Igbo } & 0.557 & 0.157 & -0.044 \\
\hline & $(0.353)$ & $(0.390)$ & $(0.147)$ \\
\hline \multirow[t]{2}{*}{ Religion (Muslim) } & $2.696 * * *$ & $1.613 * * *$ & $1.238 * * *$ \\
\hline & $(0.269)$ & $(0.268)$ & $(0.090)$ \\
\hline \multirow[t]{2}{*}{ Resources } & $0.569 * *$ & 0.312 & $0.257 * *$ \\
\hline & $(0.272)$ & $(0.293)$ & $(0.119)$ \\
\hline \multirow[t]{2}{*}{ Surface area } & $-0.453 * * *$ & $-0.294 * *$ & $-0.377 * * *$ \\
\hline & $(0.141)$ & $(0.132)$ & $(0.034)$ \\
\hline \multirow[t]{2}{*}{ International airports } & $0.585 * * *$ & $0.285 *$ & $0.314 * * *$ \\
\hline & $(0.157)$ & $(0.148)$ & $(0.036)$ \\
\hline \multirow[t]{2}{*}{ Seaports } & $1.311 * * *$ & $0.727 * * *$ & $0.678 * * *$ \\
\hline & $(0.244)$ & $(0.244)$ & $(0.067)$ \\
\hline \multirow[t]{2}{*}{ Education } & $-1.302 * * *$ & $-0.790 * * *$ & $-0.657 * * *$ \\
\hline & $(0.224)$ & $(0.222)$ & $(0.078)$ \\
\hline \multirow[t]{2}{*}{ APC states } & -0.070 & 0.063 & $0.170 * * *$ \\
\hline & $(0.174)$ & $(0.159)$ & $(0.043)$ \\
\hline \multirow[t]{2}{*}{ Constant } & $3.015 * *$ & $3.077 * *$ & $4.648 * * *$ \\
\hline & $(1.511)$ & $(1.400)$ & $(0.378)$ \\
\hline \multicolumn{4}{|l|}{ Variance/inflators: } \\
\hline \multirow[t]{2}{*}{ Cases $(-1)$} & $-0.024 * * *$ & $-0.594 * * *$ & $-0.122 * * *$ \\
\hline & $(0.004)$ & $(0.101)$ & $(0.013)$ \\
\hline \multirow[t]{2}{*}{ Yoruba } & $-0.760 * * *$ & $-0.760 * *$ & $-0.889 * * *$ \\
\hline & $(0.249)$ & $(0.312)$ & $(0.221)$ \\
\hline \multirow[t]{2}{*}{ Igbo } & $-0.745^{*}$ & -0.683 & $-0.740^{* *}$ \\
\hline & $(0.447)$ & $(0.458)$ & $(0.325)$ \\
\hline \multirow[t]{2}{*}{ Religion (Muslim) } & $-0.754 * *$ & $-0.648 *$ & $-1.176^{* * *}$ \\
\hline & $(0.321)$ & $(0.350)$ & $(0.251)$ \\
\hline \multirow[t]{2}{*}{ Resources } & -0.066 & -0.336 & -0.278 \\
\hline & $(0.344)$ & $(0.336)$ & $(0.238)$ \\
\hline \multirow[t]{2}{*}{ Surface area } & -0.194 & -0.107 & -0.095 \\
\hline & $(0.126)$ & $(0.158)$ & $(0.105)$ \\
\hline \multirow[t]{2}{*}{ International airports } & $-0.287 * *$ & $-0.376^{*}$ & $-0.320 * *$ \\
\hline & $(0.140)$ & $(0.193)$ & $(0.132)$ \\
\hline \multirow[t]{2}{*}{ Seaports } & $-0.621 * *$ & -0.302 & $-0.639 * * *$ \\
\hline & $(0.253)$ & $(0.335)$ & $(0.228)$ \\
\hline \multirow[t]{2}{*}{ Education } & 0.223 & 0.165 & $0.450 * *$ \\
\hline & $(0.205)$ & $(0.253)$ & $(0.189)$ \\
\hline APC states & 0.015 & -0.007 & 0.085 \\
\hline & $(0.150)$ & $(0.193)$ & $(0.137)$ \\
\hline Constant & $5.093 * * *$ & $2.889 *$ & $3.385 * * *$ \\
\hline & $(1.361)$ & (1.651) & (1.102) \\
\hline Wald chi $^{2}$ test & $1433.30 * * *$ & - & - \\
\hline
\end{tabular}


Table 4 (continued)

\begin{tabular}{|c|c|c|c|}
\hline \multirow[t]{2}{*}{ Variables } & \multicolumn{3}{|c|}{ Dependent variables: number of COVID-19 cases (cases) } \\
\hline & $\begin{array}{l}\text { Generalized negative binomial(GNB) } \\
1\end{array}$ & $\begin{array}{l}\text { Zero-inflated negative binomial } \\
2\end{array}$ & $\begin{array}{l}\text { Zero-inflated Poisson } \\
3\end{array}$ \\
\hline Vuong test & - & $8.15^{* * *}$ & $14.44 * * *$ \\
\hline Akaike information criterion (AIC) & 6052.74 & 5897.90 & 9995.74 \\
\hline Observations & 2380 & 2380 & 2380 \\
\hline
\end{tabular}

Standard errors are in parentheses (robust for GNB); $* * * p<0.01, * * p<0.05, * p<0.10$. The estimated values in italic forms indicate the coefficients and Wald tests are statistical significant. The Vuong tests indicate preference for zero-inflated model over those that do not account for excess zero counts

\section{Analysis of Empirical Results}

Table 3 presents the results of the separate models of political economy, multidimensional factors of COVID19 cases in Nigeria, using zero-inflated negative binomial estimator. In column one when Hausa is used as a reference group, the expected number of Igbo with COVID-19 infections is $(\exp (-0.752))=0.471$ times less than the expected number of Hausa infected by the virus. In column 2, when Igbo is used as a reference group, the expected numbers of both the Yoruba and Hausa infected by COVID-19 are 1.837 and 2.121 times, respectively than the Igbo infected by COVID-19. In the third column when Yoruba is used as a reference group for other tribes, the expected number of Igbo infected by COVID-19 is 0.544 times less than that of the Yorubas infected by the virus. On the ground of religion affiliation, the expected number of Muslims infected by the virus is $(\exp (0.1 .101))=$ 3.007 times that of the Christian counterpart. Other than resource endowments and education variables, other factors such as international airports, seaports, and party affiliation equally influence the expected number of COVID-19 cases by $1.908,1.385$, and 1.902 times those states that do not have these facilities and belong to other parties.

The lower half of the table displays the zero-regime portion of the estimated count data specification. Of the covariates, the odds of Yoruba being in the "Certain Zero" group reduce by factors of $(\exp (-0.410))=0.959$ and $(\exp (-0.463))=0.629$ times other tribes when both Hausa and Igbo are used as reference groups. Whereas the odds of Igbo and Hausa being in the "Certain Zero" group increase by factors of (exp $(0.463))=1.589$ and $(\exp (0.410))=1.509$ times the Yoruba tribe. Similarly, the odds of states with both surface and international airports lying in the "Certain Zero" group reduce by factors of 0.983 and 0.707 than states with no surface areas and international airports.

Table 4 presents the results of parameter estimates of different count data estimators namely; generalized negative binomial, zero-inflated negative binomial and zero-inflated
Poisson respectively. In view of the fact that $74.4 \%$ of the state-level observations were zeros, necessitating the use of the three-count data estimators. This, in a normative sense, suggests the absence or not too prevalent cases of COVID19 episode across the states in Nigeria. From the Table, it is apparent that the human-to-human transmission of COVID19 counts are a function of the previous period human infection. By implication, an already infected COVID-19 person can easily transmit the virus to another individual(s), especially if the necessary precautions are not taken.

For the results of generalized negative binomial specification presented in the first column of Table 4, the parameter estimates suggest that ethnic factor: Yoruba and Igbo, religion: Muslim, international airports and seaports as constituting the sources of over dispersion, as they are all negative and significant in the variance specification reported in the lower half of Table 4. For the counts of COVID-19 infection reported in the top half of the same table, variables such as ethnic affiliation: Yoruba, religion: Muslim, international airports and seaports are positive and significant. While natural resource endowments and education exert positive and significant effects on the transmission of COVID-19 across the states, even when the excess zeros are not explicitly accounted for, other than through their effects on over dispersion by the means of variance.

With respect to the results of zero-inflated negative binomial estimation, the expected number of COVID-19 cases for a Muslim in Nigeria is $(\exp (1.613))=5.018$ times the expected number of a Christian while holding all other variables in the model constant. For the surface areas, if it were to increase by a unit, the expected number of COVID-19 cases will reduce by a factor of $(\exp (-0.294))=0.745$ while holding other variables constant. Similarly, in case of international airports and seaports, a unit increase in these facilities will increase the expected number of COVID-19 cases by a factor of (exp $(0.85))=1.329$ while that of the latter will rise by a factor of $(\exp (0.727))=2.069$. The narratives for education variable show that if the level of education were to increase by a unit, it will reduce the expected number of COVID-19 transmission by a factor of 0.454 all things being equal. 


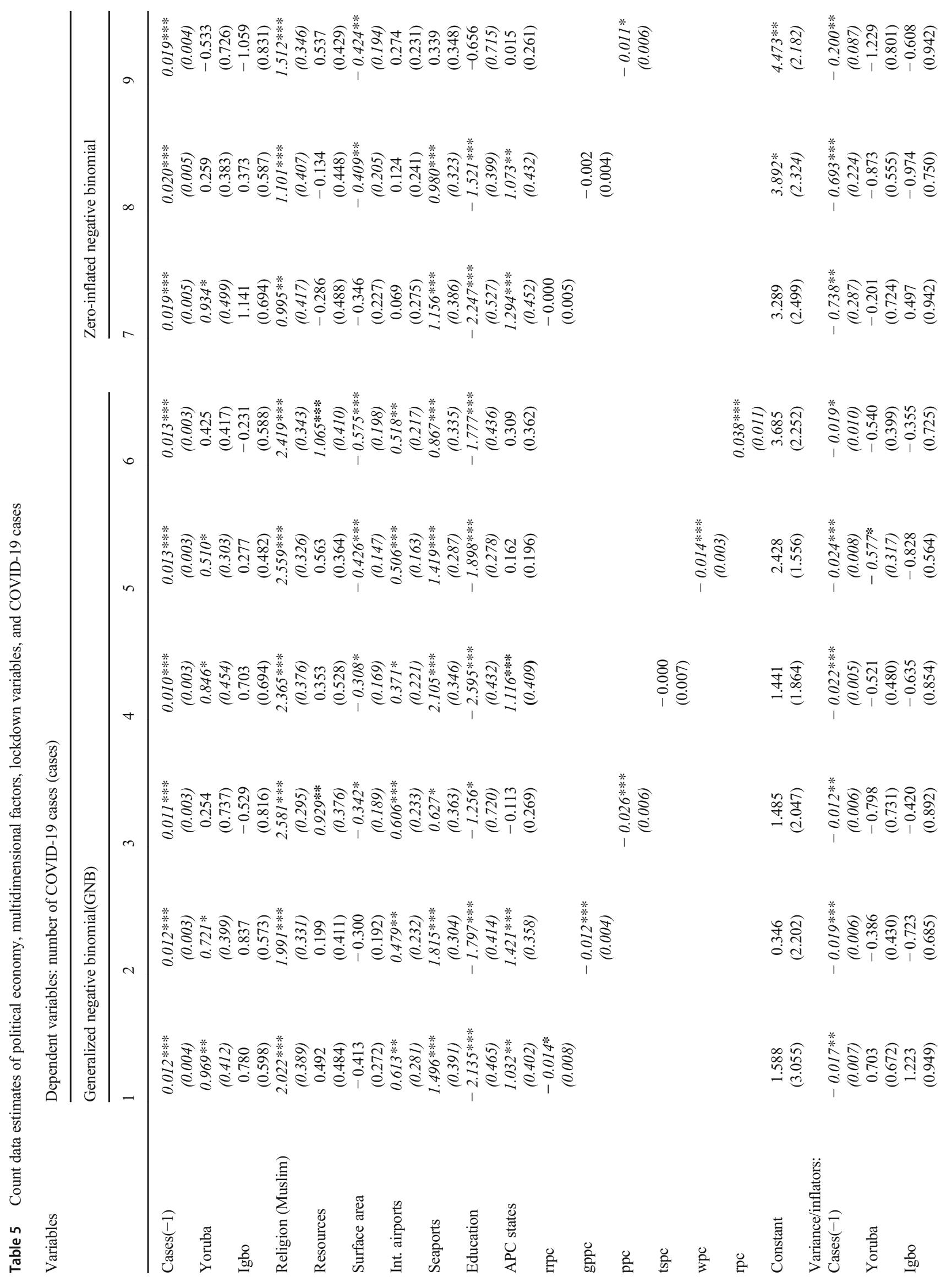




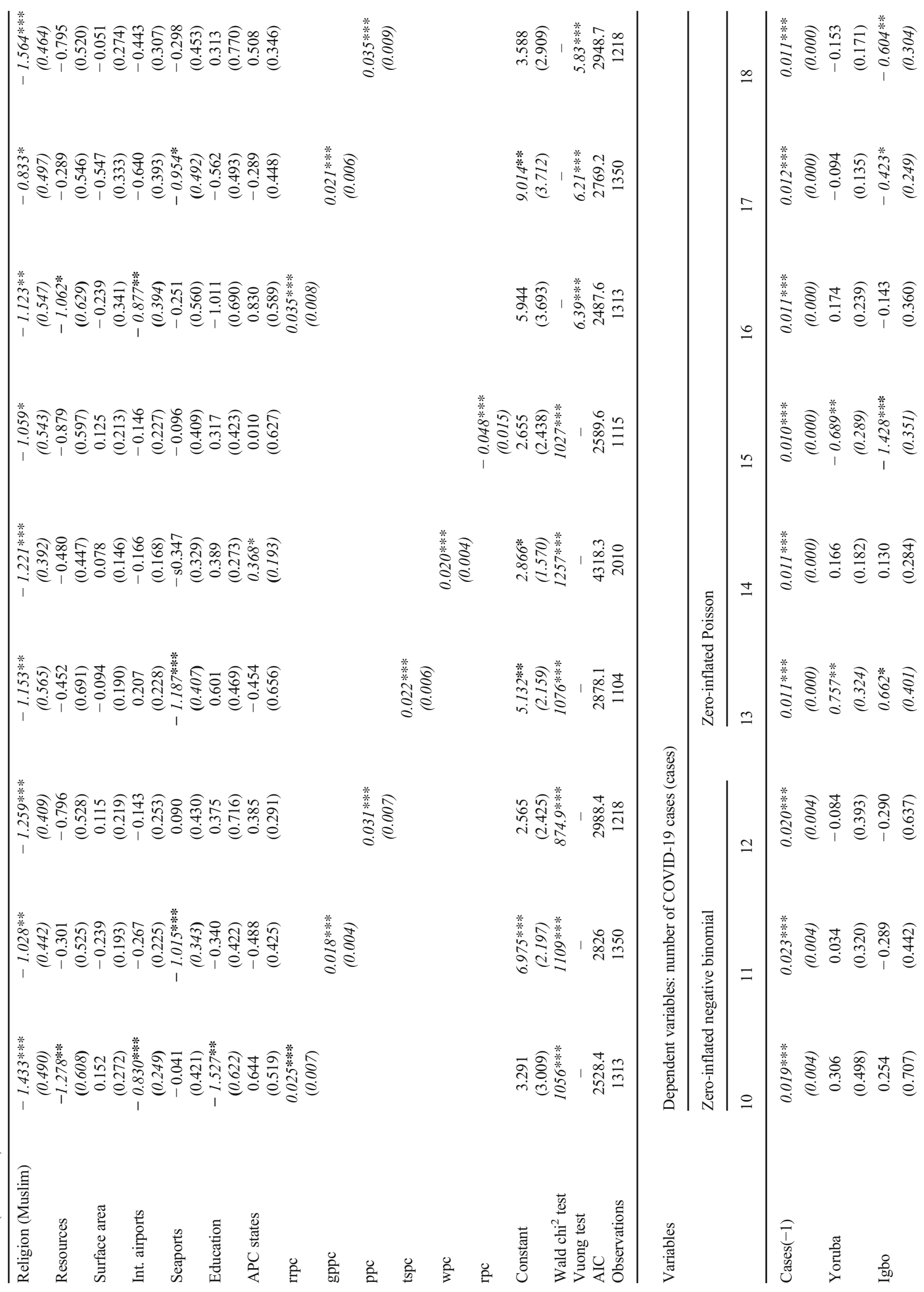




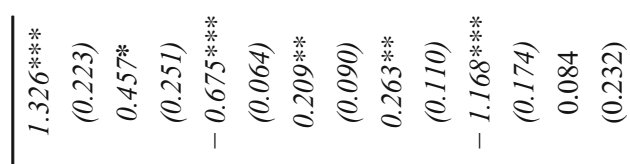

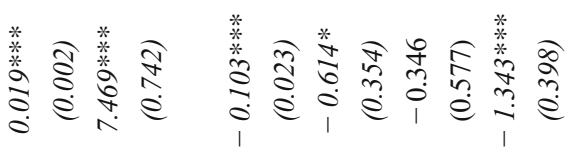

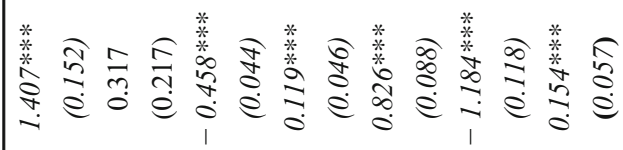

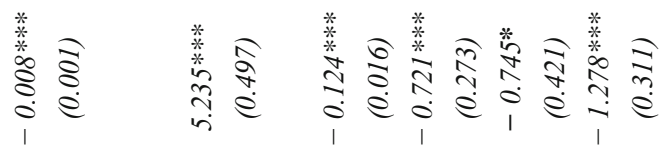

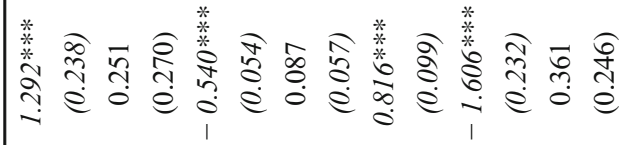

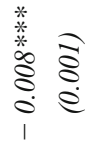

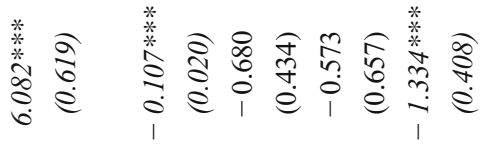

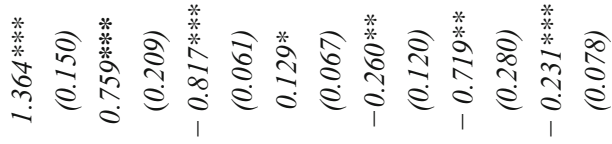

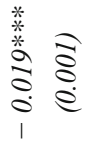

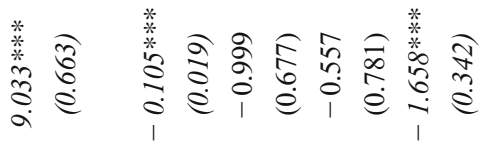

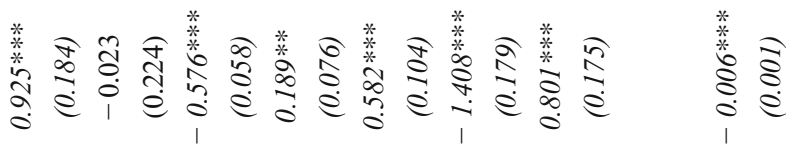

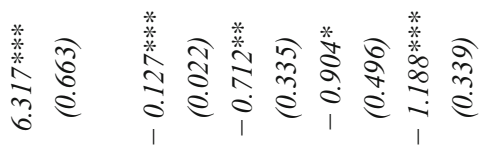

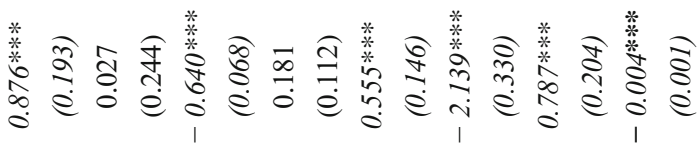

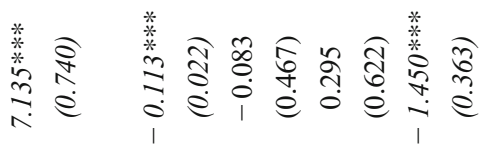

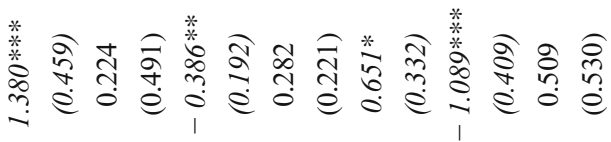

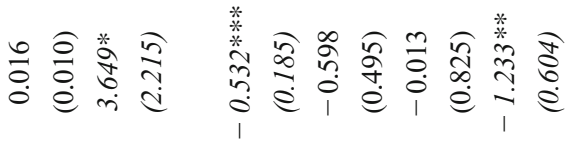

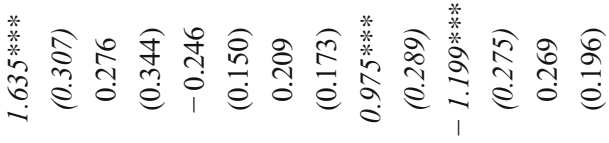

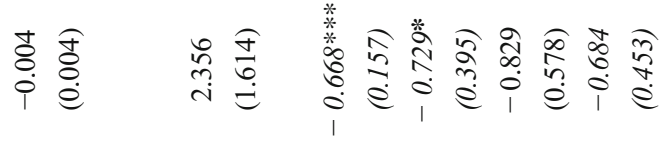

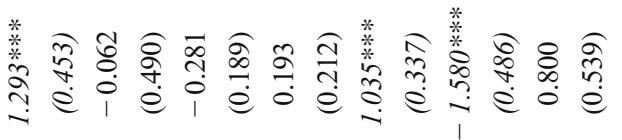

$\overline{8}$
$\dot{\delta}$
$i$
$i$

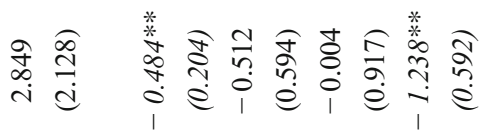

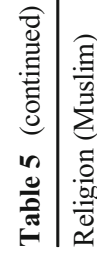
产

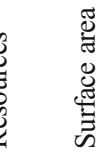

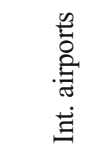
这

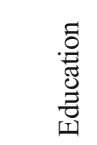

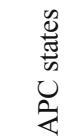

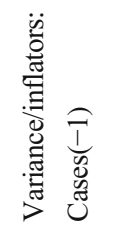

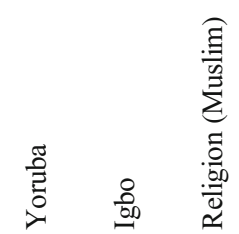




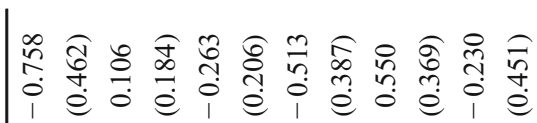

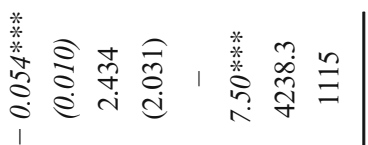

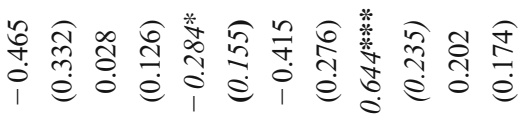

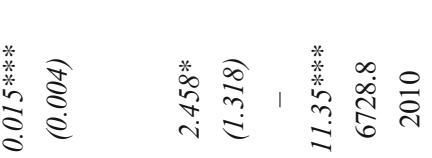

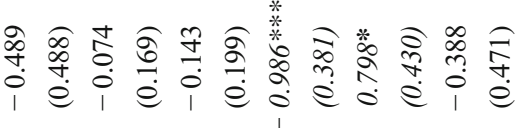

竞

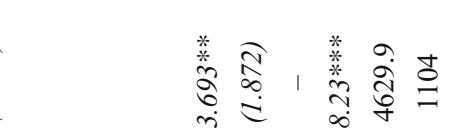

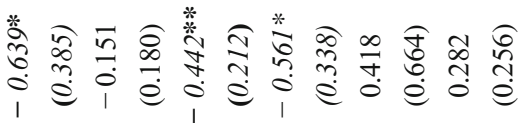

$\begin{array}{ll}* & 0 \\ * & \vdots \\ 0 & \vdots \\ 0 & 0 \\ 0 & 0\end{array}$

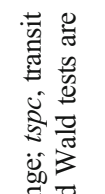

突.

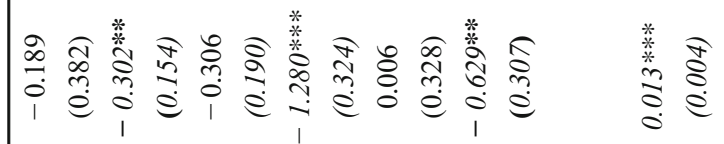

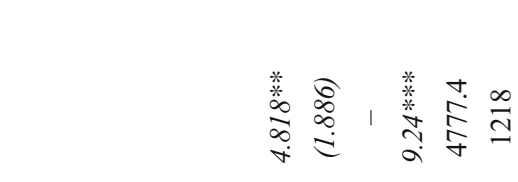

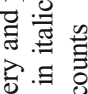

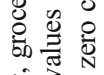

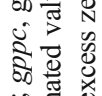

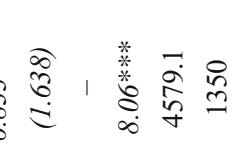

政.

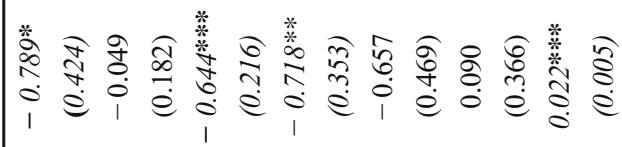

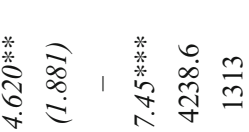

of $\mathrm{F}$

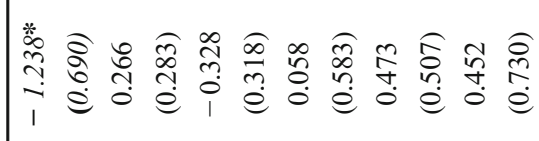

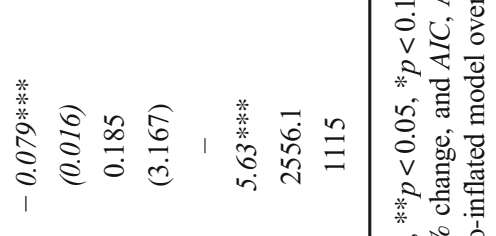

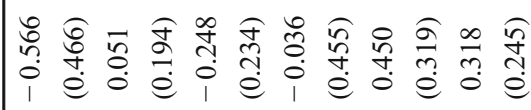

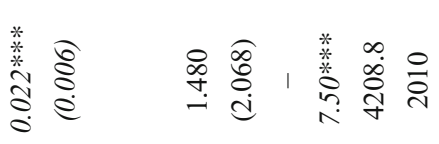

*.

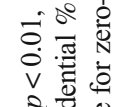

总

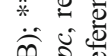

鱼导离

造

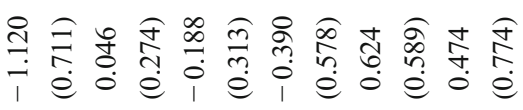

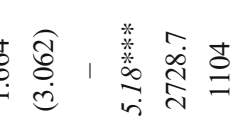

은

पू

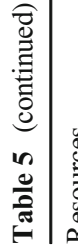

0
0
0
0
0
0 
For the zero-inflated Poisson estimator results, the narratives are not too different, expect for the changes in the magnitudes regarding the key variables of interest. For instance, the expected number of COVID-19 cases for a Muslim is $(\exp (1238))=3.4487$ times the expected number of the Christian counterpart. A unit increase in surface area will expectedly lead to a reduction by a factor of (exp $(-0.377))=0.686$ in COVID-19 spread across the states of the federation. Whereas if international airport and seaport were to increase by a unit each, the expected increase in the spread of COVID-19 virus would by rise by factors of $(\exp (0.314))=1.369$ and $(\exp (0.678))=1.970$ respectively. Similarly, a unit increase in the level of education reduces the expected number of the virus cases by a factor of $(\exp (-0.657))=0.518$.

Concerning the results of the zero-inflated negative binomial estimation, the odds of the Yoruba tribe being in the "Certain Zero" group would reduce by a factor of (exp $(-0.760))=0.468$ relative to other tribes (Hausa and Ibo). Also, the odds of Muslim being in the group would reduce by a factor of $(\exp (-0.648))=0.523$ relative to the Christian counterpart. Similarly, the odds of a variable of international airport being in the "Certain Zero" group reduce by a factor of $(\exp (-0.376))=0.687$. The tales do not significantly different for zero-inflated Poisson estimator except for the magnitude of impacts.

However, since the Akaike Information Criterion (AIC) serves as a measure of model adequacy, suggesting that the smaller the AIC of an estimated specification, the lower is the discrepancy between it and the true population model (see, Price 2019: 171 for more exposition). The implication of the foregoing is that we rely more on the results reported for the zero-inflated negative binomial regression.

Table 5 shows the estimated outcomes of political economy, multidimensional factors of COVID-19 in Nigeria, accounting specially for the lock-down effect. Of the three estimated results presented, the AIC for the zero-inflated negative binomial regression appears to be the least, thus suggesting discrepancy between the estimated and true population to be relatively smaller as compared to other estimators. Thus, efforts will be channeled discussing only the results of the zero-inflated negative binomial regression. Of the lockdown variables including retail and recreation, grocery and pharmacy, parks, transit stations and work places, the estimated number in the percentage change in parks reduces the incidence of COVID-19 by a factor of 0.989 .

However, in the lower half of the table, the odds of percentage changes in retail and recreation, grocery and pharmacy, parks, transit stations, and workplaces being in the "Certain Zero" zone increase while than of residential reduce across the models.

\section{Discussion of Results}

After cross-examining Tables 3, 4 and 5, five consistent findings worth elucidating. First, the human-to-human transmission of COVID-19 virus is expected to be more among the Hausas than other tribes when other confounding factors are not included in the model. This is not unexpected as the majority of Hausas are uneducated. The observed differences in the levels of educational attainment between the North and South regions of the country has been argued to be facilitated by non-intervention in matters of religion or "tradition" of the former by the colonial masters (Mustapha 2006; Dudley 2013). Also, the compliant behavior towards the federal structure regime in the military postcolonial autocracy is found to be associated with more development outcomes than belonging to non-compliant group (See, Archibong 2018 for detailed exposition). This is consistent with studies that have established a positive relationship between pre-colonial centralization and current development outcomes (Michalopoulos and Papaioannou 2013; Osafo-Kwaako and Robinson 2013; Fenske 2014; Archibong 2017). Second, the expected number of COVID-19 infected people appears to be more among the Muslims than the Christian counterpart. This seems plausible, as the Muslims constitute the majority in Nigeria. This is well depicted on the summary statistics table where the Muslims averaged about $68 \%$ of the population. This is so as majority of the Muslims are Hausas who do not believe in the existence of COVID-19. This is even more evident in their slogans at the emergence of the virus "Babu Corona" (meaning there is no coronavirus). The reason for such utterances may not be farfetched from their staunch belief in Quran (the Muslims' scriptural book) and other Islamic injunctions relating to the act of soul taking. For instance, in Chapter 7 verse 4 of the Quran, which reads thus: "to every people is an appointed time; when the time is reached, such souls will not be spared a second nor be extended". In another Chapter, precisely Chapter 63 verse 11, it reads: but never will Allah (God) delays a soul when the time has reached.

Third, the expected number of people infected by virus is found to be higher for both international airports and seaports. However, the odds of states with international airports being in the "Certain Zero" regime are less than states without one. International airports and seaports are routes through which the virus is transmitted. This explains why many countries in the world closed their borders and ports upon the emergence of the virus. Fourth, the odds of lockdown variables including retail and recreation, grocery and pharmacy, parks, transit stations and work places being in the "Certain Zero" region increase than that of the residential houses across the model specifications. While the lockdown exercise is found to be effective in parks, grocery and recreation centers, and transit stations on the one hand, the residential houses cannot be effectively monitored particularly with respect to social 
distancing on the other hand. This latter situation creates the avenue through the virus is transmitted. It is interesting to note that all the lockdown variables are significant predictors of COVID-19 cases. It is worth mentioning that while the retail and recreation, grocery and pharmacy, parks, transit stations, workplaces exert negative effects on COVID-19 cases on one hand, residential acts as a magnifying tool for COVID-19 on the other hand. The positive coefficient on the latter variable may be explained by the following (i) boredom usually does not allow some people stay at home for a very long time thereby making them flout the lockdown rules and (ii) some couples are simply intolerant of each other. Anecdotal instances abound. During the present lockdown exercise, some couples have been reportedly killed, and there is lot of reported domestic violence on the newspapers headlines. Lastly, the previous incident of COVID-19 increases the expectation of the current COVID-19 cases.

\section{Conclusion and Policy Implications}

Since the emergence of COVID-19 virus, research efforts have been rigorously channeled at examining clinical and epidemiological impacts and consequences of the virus, with little or nothing known about the political economy and other multidimensional factors driving it, particularly from country-specific dimension. This paper deploys a variety of count data estimators to estimate the effects of political economy and ethno-religious factors on COVID19 cases in Nigeria. The parameter estimates reveal that the odds of the Hausa ethnic group in human-to-human transmission of the virus to be in the "Certain Zero" group is relatively less than other ethnic groups in Nigeria. The reasons for this outcome, particularly for the vulnerable group, can be attributed, in part, to their low levels of educational attainment as well as their staunch religious belief with respect to the act of soul taking as being the exclusive property of the creator than the created. What is more, the useful roles of other multidimensional factors such as party affiliations, international airports, seaports, and lock down variables particularly, the residential sector cannot equally be undermined.

The study findings have some relevant policy implications. As our parameter estimates suggest that for any mitigation policies to stem the spread of COVID-19 at all, ethnoreligious and socioeconomic implications of the virus should not be undermined. As our results are based on Nigeria, the need to ensure and maintain equal balance among the various ethnic groups seems sacrosanct, as lopsidedness particularly with respect to some key growth ingredients (e.g., education, other infrastructural facilities) often reduce the cost of the virus spread.

Fanaticism in religious matter constitutes a potentially surest route through which a virus spread, this often being the case as issues are usually viewed from extreme perspective. Thus, the need to moderate extremism should be upheld with full force of laws if be needed. In addition, politicization that often characterizes the federal system of government should be cautiously guided against, most especially, if human lives are involved. This can be minimized if not eliminated if the government is sincere in their provision and delivery of public goods. This is particularly important, as the former historical institutions versus compliant-non-compliant state actors had been held culpable as causing ethnic inequalities that characterized access to federal resources; such should be eschewed for health-related matters, like COVID. Government needs to be proactive in its decisions and actions such that the recurrence of the previous COVID-19 incident can be averted. This can be achieved, if those that had contacted the virus are well quarantined so as not to spread the virus. What is more, the closure of international airports and seaways should continue to be upheld for the time being. Lastly, the lockdown measures particularly those relating to residential houses should be properly enlightened about the dangers inherent in the spread of the virus.

\section{Compliance with Ethical Standards}

Conflict of Interest The authors declare that they have no conflict of interest.

\section{Appendix 1: List of states in Nigeria}

Lagos, Ogun, Ekiti, Kwara, Oyo, Edo, Bauchi, Enugu, Osun, Benue, Kaduna, Akwalbom, Ondo, Delta, Katsina, Niger, Anambra, Kano, Borno, Jigawa, Abia, Gombe, Sokoto, Adamawa, Plateau, Zamfara, Imo, Taraba, Bayelsa, Ebonyi, Kebbi, Nasarawa, and Yobe. 


\section{Appendix 2}

Table 6 Definition of variables

\begin{tabular}{|c|c|c|c|}
\hline Signs & Variables & Measurement & Sources \\
\hline Cases & Cases & $\begin{array}{l}\text { Number of reported COVID-19 } \\
\text { cases }\end{array}$ & Nigeria Centre for Disease Control (NCDC 2020) \\
\hline Yoruba & Yoruba & States dominated by Yoruba tribe & The World Fact (2018). 1 is assigned to Yoruba states and 0 if otherwise. \\
\hline Igbo & Igbo & States dominated by Yoruba tribe & The World Fact (2018). 1 is assigned to Igbo states and 0 if otherwise. \\
\hline Hausa & Hausa & States dominated by Hausa tribe & The World Fact (2018). 1 is assigned to Hausa states and 0 if otherwise. \\
\hline Muslim & Religion(Muslim) & Muslim-dominated states & $\begin{array}{l}\text { The World Fact (2018). } 1 \text { is assigned to Muslim dominated states and } 0 \text { if } \\
\text { otherwise. }\end{array}$ \\
\hline Christian & Religion(Christian) & Christian-dominated states & $\begin{array}{l}\text { The World Fact (2018). } 1 \text { is assigned to Christian dominated states and } 0 \text { if } \\
\text { otherwise. }\end{array}$ \\
\hline Res & Resources & $\begin{array}{l}\text { States with natural resources } \\
\text { abundance }\end{array}$ & $\begin{array}{l}\text { National Bureau of Statistics (2019). } 1 \text { is assigned to states with vast resources and } \\
0 \text { if otherwise. }\end{array}$ \\
\hline surface & Surface area & Surface area & World Gazetteer (2013) \\
\hline intspt & International airport & International airports & $\begin{array}{l}\text { Federal Airports Authority of Nigeria (FAAN 2020). } 1 \text { is assigned to states with } \\
\text { international airport whereas } 0 \text { if otherwise. }\end{array}$ \\
\hline seapt & Seaports & Seaports & $\begin{array}{l}\text { Nigerian Ports Authority (NPA 2020). } 1 \text { is assigned to states with major seaports } \\
\text { whereas } 0 \text { if otherwise. }\end{array}$ \\
\hline edu & Education & Education & $\begin{array}{l}\text { National Bureau of Statistics (2018). } 1 \text { is assigned to states that have their literacy } \\
\text { rate above } 50 \% \text { and } 0 \text { to those below } 50 \% \text {. }\end{array}$ \\
\hline apc & APC states & $\begin{array}{l}\text { States controlled by APC } \\
\text { governors }\end{array}$ & $\begin{array}{l}\text { Independent National Electoral Commission (INEC 2020). } 1 \text { for the APC } \\
\text { controlled states, } 0 \text { if otherwise }\end{array}$ \\
\hline napc & Non-APC states & $\begin{array}{l}\text { States controlled by non-APC } \\
\text { governors }\end{array}$ & $\begin{array}{l}\text { Independent National Electoral Commission (INEC 2020). } 1 \text { for non-APC } \\
\text { controlled states, } 0 \text { if otherwise }\end{array}$ \\
\hline $\operatorname{rrpc}$ & $\begin{array}{l}\text { Retail and recreation } \\
\% \text { change }\end{array}$ & $\begin{array}{l}\text { Retail and recreation percent } \\
\text { change from baseline }\end{array}$ & NCDC (2020) \\
\hline gppc & $\begin{array}{l}\text { Grocery and } \\
\text { pharmacy } \% \\
\text { change }\end{array}$ & $\begin{array}{l}\text { Grocery and pharmacy percent } \\
\text { change from baseline }\end{array}$ & NCDC (2020) \\
\hline ppc & Parks $\%$ change & $\begin{array}{l}\text { Parks percent change from } \\
\text { baseline }\end{array}$ & NCDC (2020) \\
\hline tspc & $\begin{array}{l}\text { Transit stations } \% \\
\text { change }\end{array}$ & $\begin{array}{l}\text { Transit stations percent change } \\
\text { from baseline }\end{array}$ & NCDC (2020) \\
\hline wpc & $\begin{array}{l}\text { Workplaces } \% \\
\text { change }\end{array}$ & $\begin{array}{l}\text { Workplaces percent change from } \\
\text { baseline }\end{array}$ & NCDC (2020) \\
\hline $\mathrm{rpc}$ & Residential \% change & $\begin{array}{l}\text { Residential percent change from } \\
\text { baseline }\end{array}$ & NCDC (2020) \\
\hline
\end{tabular}

\section{References}

Ajide KB, Ibrahim RL, Alimi OY. Estimating the impacts of lockdown on Covid-19 cases in Nigeria. Transp Res Interdiscip Perspect. 2020;7(2020):100217. https://doi.org/10.1016/j.trip. 2020.100217.

Al-Raddadi RM, Shabouni OI, Alraddadi ZM, Alzalabani AH, AlAsmari AM, Ibrahim A, et al. Burden of Middle East respiratory syndrome coronavirus infection in Saudi Arabia. J Infect Publ Health. 2020;13(5):692-6.

Altamimi A, Ahmed A. Climate factors and incidence of Middle East respiratory syndrome coronavirus. J Infect Publ Health. 2020;13(5): 704-8. https://doi.org/10.1016/j.jiph.2019.11.011.

Archibong B. Where local kings rule: Long-term impacts of precolonial institutions and geography on access to public infrastructure services in Nigeria. CDEP-CGEGWorking Paper No. 21. 2017. Available at https://academiccommons.columbia.edu/doi/10.7916/D8HX1D8X. Accessed 5 May 2020.

Archibong B. Historical origins of persistent inequality in Nigeria. Oxf Dev Stud. 2018;46(3):325-47. https://doi.org/10.1080/13600818. 2017.1416072.

Briz-Redón Á, Serrano-Aroca Á. A spatio-temporal analysis for exploring the effect of temperature on COVID-19 early evolution in Spain. Sci Total Environ. 2020;728:138811. https://doi.org/10.1016/j. scitotenv.2020.138811.

Ceylan Z. Estimation of COVID-19 prevalence in Italy, Spain, and France. Sci Total Environ. 2020;729:138817. https://doi.org/10. 1016/j.scitotenv.2020.138817.

Daniel L. The coronavirus crisis, governance, social and political economy issues (a short note). Ann Soc Sci Manag Stud. 2020;5(2):42-6. 
Dudley BJ. Parties and politics in northern Nigeria. London: Routledge; 2013.

Federal Airports Authority of Nigeria (FAAN). List of airports owned and managed by FAAN. 2020. Available at http://www.faannigeria. org/nigeria-airport.php. Accessed 7 May 2020.

Federation Account Committee (FAAC). National Bureau of Statistics/ Office of The Accountant General of The Federation. 2020. Available at https://www.nigerianstat.gov.ng/pdfuploads/ Federation_Account_Allocation_Committee_(FAAC)_FEB_ 2020 Disbursement.pdf. Accessed $\overline{7}$ May 2020.

Fenske J. Ecology, trade, and states in pre-colonial Africa. J Eur Econ Assoc. 2014;12(3):612-40.

Ferdinand KC, Nasser SA. African American COVID-19 mortality: a sentinel event. J Am Coll Cardiol. 2020;75(21):2746-8.

Greene WH. Accounting for excess zeros and sample selection in Poisson and negative binomial regression models. New York University Working Paper No. EC-94-10. https://ssrn.com/abstract=1293115. Accessed 11 May 2020.

Greer SL, King EJ, da Fonseca EM, Peralta-Santos A. The comparative politics of COVID-19: the need to understand government responses. Glob Public Health. 2020;15(9):1413-6.

Guliyev H. Determining the spatial effects of COVID-19 using the spatial panel data model. Spatial Statistics. 2020;38:1-10.

Ibrahim RL, Ajide KB, Julius OO. Easing of lockdown measures in Nigeria: implications for the healthcare system. Health Policy Technol. 2020. https://doi.org/10.1016/j.hlpt.2020.09.004.

Independent National Electoral Commission (INEC). List of newly elected governors in Nigeria 2019 with election statistics. 2020. Available at https://www.naijadazz.com/nigerian-governors/. Accessed 8 May 2020.

Lambert D. Zero-inflated poisson regression, with an application to defects in manufacturing. Technometrics. 1992;34:1-14.

LeVan AC, Ukata P. The oxford handbook of Nigerian politics. Oxford: Oxford University Press; 2018.

Michalopoulos S, Papaioannou E. Pre-colonial ethnic institutions and contemporary African development. Econometrica. 2013;81(1): 113-52.

Mustapha AR. Ethnic structure, inequality and governance of the public sector in Nigeria. Geneva: United Nations Research Institute for Social Development; 2006.

National Bureau of Statistics. Literacy rate. 2018. Available at https:// www.nigerianstat.gov.ng/. Accessed 11 May 2020.

National Bureau of Statistics. Population. 2019. Available at https:// www.nigerianstat.gov.ng/. Accessed 11 May 2020.

NCDC. Situation report. 2020. Online at https://covid19.ncdc.gov.ng/. Accessed 7 May 2020.

Nicola M, Alsafi Z, Sohrabi C, Kerwan A, Al-Jabir A, Iosifidis C, Agha M, Agha R. The socio-economic implications of the coronavirus and COVID-19 pandemic: a review. Int J Surgery. 2020;78:185-93.

Nigerian Ports Authority (NPA). Major seaports in Nigeria. 2020. Available at https://nigerianports.gov.ng/. Accessed 7 May 2020.

Osafo-Kwaako P, Robinson JA. Political centralization in pre-colonial Africa. J Comp Econ. 2013;41(1):6-21.

Price GN. Does productivity in the formal food sector drive human Ebola virus infections in sub-Saharan Africa? Afr Dev Rev. 2019;31:16778.

Price GN, Elu JU. Climate change and cross-state Islamist terrorism in Nigeria. Peace Econ, Peace Sci Publ Policy. 2017;23(3):20160047. https://doi.org/10.1515/peps-2016-0047.

Saleh M. Impact of COVID-19 on Tanzania political economy. Int J Adv Std in Soc Sci Innov. 2020;4(1):24-36.

Shaw R, Kim YK, Hua J. Governance, technology and citizen behavior in pandemic: lessons from COVID-19 in East Asia. Progress Disaster Sci. 2020;100090(6):100900. https://doi.org/10.1016/j.pdisas.2020. 100090.

The World Factbook. Central Intelligence Agency. 2018. Available at https://www.cia.gov. Accessed 8 May 2020.

The World Factbook. Nigeria: people, CIA World Factbook. 2019. Available at https://www.cia.gov/library/publications/the-worldfactbook/fields/401.html. Accessed 8 May 2020.

Tosepu R, Gunawan J, Effendy DS, Lestari H, Bahar H, Asfian P. Correlation between weather and Covid-19 pandemic in Jakarta, Indonesia. Sci Total Environ. 2020;725:138436. https://doi.org/10. 1016/j.scitotenv.2020.138436.

Wang L, Li J, Guo S, Xie N, Yao L, Cao Y, et al. Real-time estimation and prediction of mortality caused by COVID-19 with patient information-based algorithm. Sci Total Environ. 2020;727:138394. https://doi.org/10.1016/j.scitotenv.2020.138394.

World Gazetteer. Nigeria: Administrative division (population and area). 2013. Available at https://archive.is/20130105064307/http://www. world-gazetteer.com/wg.php\#selection-119.5-10.9. Accessed 10 May 2020.

Worldometer. COVID-19 coronavirus pandemic. 2020. Available at https://www.worldometers.info/coronavirus/. Accessed 11 May 2020.

Zhao S, Lin Q, Ran J, Musa SS, Yang G, Wang W, et al. Preliminary estimation of the basic reproduction number of novel coronavirus (2019-nCoV) in China, from 2019 to 2020: a data-driven analysis in the early phase of the outbreak. Int J Infect Dis. 2020;92:214-7.

Zorn CJW. An analytic and empirical examination of zero-inflated and hurdle Poisson specifications. Sociol Methods Res. 1998;26:368400 .

Publisher's Note Springer Nature remains neutral with regard to jurisdictional claims in published maps and institutional affiliations. 